Bangladesh J. Bot. 47(3): 501-508, 2018 (September)

\title{
ESTIMATION OF BROAD-SENSE HERITABILITY AND VARIANCE COMPONENTS FOR SEED YIELD AND AGRONOMIC TRAITS IN NATIVE AND EXOTIC SAFFLOWER (CARTHAMUS TINCTORIUS L.) GENOTYPES
}

\author{
Zahra Tahernezhad*, Jalal Saba, Mehrshad Zeinalabedini ${ }^{1}$, \\ Seyyed Saeid Pourdad ${ }^{2}$ and Mohammad Reza Ghaffari ${ }^{1}$ \\ Department of Agronomy and Plant Breeding, Faculty of Agriculture, \\ University of Zanjan, 45371-38791 Zanjan, Iran
}

Keywords: Heritability, Variance, Agronomic traits, GCV, PCV

\begin{abstract}
This study was conducted to estimate broad-sense heritability and variance components for seed yield and some agronomic traits in 100 safflower genotypes. The experiments were carried out in two years at two locations in Iran. The number of seeds per capitol and harvest index had the highest genotypic coefficient of variation $(\mathrm{GCV})$ and phenotypic coefficient of variation (PCV), respectively. The estimated broad-sense heritability for plant height, days to physiological maturity, 1000-seed weight, days to flowering, number of seeds per capitol, number of capitols per plant and seed yield were 86, 76, 74, 70, 68, 44 and 16\%, respectively. It was found that plant height, days to physiological maturity, 1000-seed weight, days to flowering and number of seeds per capitol were the least influenced by the environment. The number of capitols per plant and seed yield were most affected by the environment.
\end{abstract}

\section{Introduction}

Safflower (Carthamus tinctorius L.) belonging to the family Compositae (Asteraceae). It is diploid $(2 \mathrm{n}=2 \mathrm{x}=24)$ and is commonly self-compatible and self-pollinated. Cross-pollination occurs naturally (Mundel and Bergman 2009). Among oil seed crops, only the safflower originates from Iran and the Middle East. It is a common plant with high adaptability, low water requirements and drought resistance (Ashri et al. 1975). Safflower has been used for 4,000 years as a coloring agent because it contains, Carthamin, which is extracted from the petals. Carthamin has been used for food coloring in rice, bread, and cheese, as well as in clothing and carpets (Pourdad 2006). The color and shape of the tubular florets of the safflower are similar to saffron, and it has been used as a cheaper alternative to and is sometimes fraudulently sold as saffron ( $\mathrm{Li}$ and Mundel 1996).

The primary aim of safflower production is the extraction of the seed oil, which is of good quality for different applications. Some seed oil genotypes contain 75 to $80 \%$ oleic acid, which is comparable regarding quality to olive oil (Li and Mundel 1996). Safflower oil is high in linoleic acid and is used in cooking, margarine production and for industrial purposes. Safflower seeds contain 25 to $45 \%$ oil and 12 to $24 \%$ protein (Weiss 2000).

Yield can be improved by selection of high yield traits or components through selective breeding to reduce morphological and physiological factors that can decrease yield. Breeding for yield components is useful when the components are highly heritable, genetically independent, have a positive correlation and are physiologically independent or connected in a positive manner

*Author for correspondence: <z_tahernezhad@znu.ac.ir>. ${ }^{1}$ Systems Biology Department, Agricultural Biotechnology Research Institute of Iran Agricultural Research, Education and Extension Organization (AREEO), 31359-33151 Karaj, Iran. ${ }^{2}$ Dryland Agricultural Research Institute, Agricultural Research, Education and Extension Organization (AREEO), 1164- 67145 Kermanshah, Iran. 
(Bleidere 2002). A positive response to selection in breeding programs and performance depends on the ability to predict the genotype by observation of the phenotype. This also depends on the magnitude of environmental effects, number of observations and genetic variance (Al-Yassin et al. 2005).

The most important traits are plant height, first branch height, number of branches, capitol diameter, number of seed per capitol, 1000-seed weight and oil content because of their direct or indirect correlation with yield (Omidi-Tabrizi 2005). Many of these traits are influenced by environmental effects and genetic differences; therefore, heritability should be estimated to optimize breeding programs (Camas and Esendal 2006). In quantitative traits, measuring the relationship between genotype and phenotype determines their heritability (Al-Yassin et al. 2005). Some researchers believe that the estimation of heritability can help to determine the effects of the environment on the expression of genotypes (Reddy et al. 2013). The present study estimated heritability through estimation of variance components and determination of environmental effects on agro-morphological traits, especially safflower grain yield.

\section{Materials and Methods}

One hundred genotypes of safflower (landrace accessions, cultivars and advanced lines from Iran and other countries) were sown in a simple lattice $(10 \times 10)$ design with two replications in two environments (Table 1). Environment 1 was located at the research field of the Faculty of Agriculture of the University of Zanjan $\left(36^{\circ} 40^{\prime} \mathrm{N}\right.$ and $48^{\circ} 29^{\prime} \mathrm{E}$, elevation: $1663 \mathrm{~m}$, average annual temperature: $11.5^{\circ} \mathrm{C}$ ). The genotypes were sown during April 2014 at this location. Environment 2 was located in the research fields of the Faculty of Agriculture at the University of Tehran outside the city of Karaj $\left(35^{\circ} 50^{\prime} \mathrm{N}\right.$ and $51^{\circ} 00^{\prime} \mathrm{E}$, elevation: $1300 \mathrm{~m}$, average annual temperature: $\left.14.4^{\circ} \mathrm{C}\right)$. The genotypes were sown during April 2015 at this location.

The experimental plots were of $1.5 \times 1 \mathrm{~m}$ in size with three rows and $50 \mathrm{~cm}$ row spacing. Both fields were irrigated. Environment 1 was drip irrigated and environment 2 was sprinkler irrigated. The traits measured were days to $50 \%$ flowering, days to physiological $(\mathrm{mm})$, plant height $(\mathrm{cm})$, capitol diameter $(\mathrm{mm})$, number of capitols per plant, number of seed per capitol,1000seed weight $(\mathrm{g})$, seed yield per plant $(\mathrm{g})$ and harvest index per plant.

Combined analysis of variance (ANOVA) was first carried out for the simple lattice design using the SAS statistical program $\left(9.1 .3 \mathrm{v}\right.$.). Genotypic $\left(\sigma_{\mathrm{g}}^{2}\right)$ and phenotypic $\left(\sigma_{\mathrm{ph}}^{2}\right)$ variances were obtained from ANOVA of the components using the methods suggested by Viana and Regazzi (1999) and Toker (2004), respectively, as:

$$
\begin{aligned}
& \sigma_{\mathrm{g}}^{2}=[(\mathrm{k}+1) / \mathrm{k}]\left[\left(\mathrm{MS}_{\mathrm{g}}-\mathrm{MS}_{\mathrm{ge}}\right) / \mathrm{re}\right] \\
& \sigma_{\mathrm{ph}}^{2}=\sigma_{\mathrm{g}}^{2}+\sigma_{\mathrm{ge}}^{2} / \mathrm{e}+\sigma_{\mathrm{e}}^{2} / \mathrm{re}
\end{aligned}
$$

where, $\mathrm{r}$ is the number of replication, $\mathrm{MS}_{\mathrm{g}}$ is the mean square (adj) for genotype, $\mathrm{MS}_{\mathrm{ge}}$ is the mean square for genotype $\times$ environment interaction, $\mathrm{k}$ is the number of incomplete blocks, $\mathrm{e}$ is the number of environments and $\sigma_{\text {ge }}^{2}$ is the variance for genotype $\times$ environment interaction. Broad-sense heritability $\left(\mathrm{h}_{\mathrm{b}}{ }_{\mathrm{b}}\right)$ was estimated using the method suggested by Hill et al. (1998) as:

$\mathrm{h}_{\mathrm{b}}^{2}=\sigma_{\mathrm{g}}^{2} / \sigma_{\mathrm{ph}}^{2}$

The genotypic (GCV) and phenotypic coefficients of variation (PCV) were calculated using the method suggested by Singh and Chaudhury (1985) as:

$$
\begin{aligned}
& \operatorname{GCV}(\%)=\left(\sqrt{ } \sigma_{g}^{2} / \bar{x}\right) \times 100 \\
& \operatorname{PCV}(\%)=\left(\sqrt{ } \sigma_{p h}^{2} / \bar{x}\right) \times 100
\end{aligned}
$$

where, $\sigma_{\mathrm{g}}^{2}$ is the genotypic variance, $\sigma_{\mathrm{ph}}^{2}$ is the phenotypic variance and $\bar{x}$ is the total mean. 


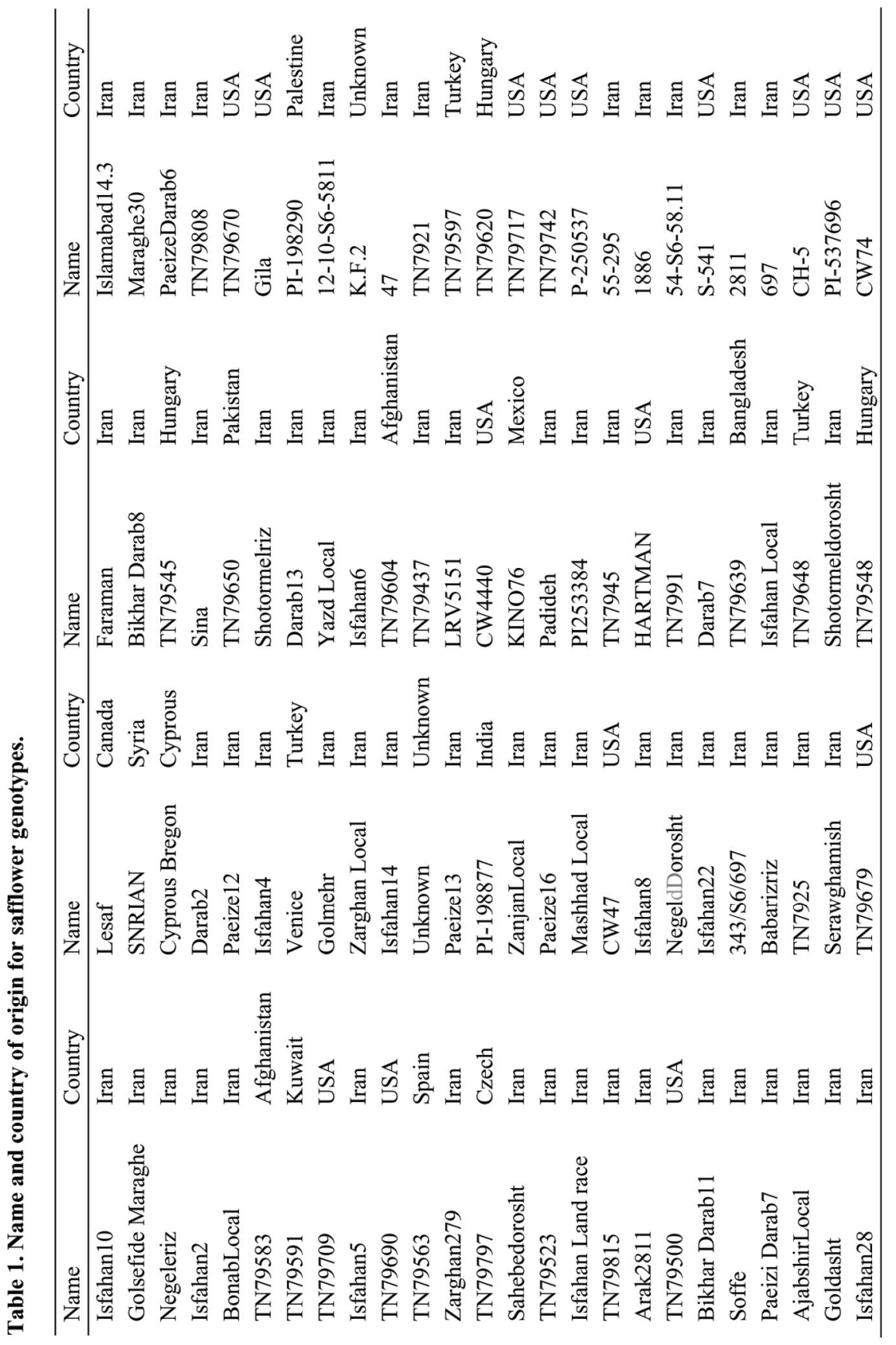




\section{Results and Discussion}

Combined ANOVA revealed significant differences between environments for all traits except number of capitols per plant, number of primary branches per plant and harvest index (Table 2). The 1000-seed weight and seed yield were higher in environment 1 than in environment 2 , but environment 2 showed significantly greater outer bract width, outer bract length, capitol diameter, number of seeds per capitol, days to $50 \%$ flowering, days to physiological maturity and plant height (Table 3). There was a significant difference between genotypes for all traits (Table 2). The average seed yield per plant was $5.98-42.75 \mathrm{~g}$. The highest ranges $(45-124.8 \mathrm{~cm})$ were found for plant height and number of seeds per capitol (15 - 93.6). The number of primary branches $(5-14.3)$ and harvest index (0.049 - 0.598) showed the lowest ranges (Table 4).

Table 2. Results of combined ANOVA for seed yield and agronomic traits of safflower genotypes.

\begin{tabular}{lllllll}
\hline \multirow{2}{*}{$\begin{array}{l}\text { Source of } \\
\text { variance }\end{array}$} & df & \multicolumn{5}{c}{ MS } \\
\cline { 3 - 7 } & & DF & DM & PBN & OBW & OBL \\
\hline Environment & 1 & $4888.96^{* *}$ & $398.56^{*}$ & 1.61 & $478.82^{*}$ & $6870.72 * *$ \\
Rep/environment & 2 & $7.52^{*}$ & $16.29 * *$ & $14.98^{* * *}$ & $8.61^{*}$ & 12.53 \\
Block/ (environment $\times$ rep) & 36 & $3.15^{* *}$ & $4.48^{* *}$ & $1.47^{* *}$ & 1.61 & $11.50^{*}$ \\
Genotype & 99 & $114.43^{* * *}$ & $126.22^{* * *}$ & $4.33^{* * *}$ & $12.55^{* * *}$ & $64.35^{* * *}$ \\
Environment $\times$ genotype & 99 & $46.36^{* * *}$ & $27.93^{* * *}$ & $2.61^{* * *}$ & $3.99^{* * *}$ & $15.23^{* * *}$ \\
Error & 162 & 1.8 & 2 & 0.77 & 1.89 & 7.1 \\
CV $(\%)$ & & 10.21 & 6.18 & 19.23 & 19.33 & 25.62 \\
\hline
\end{tabular}

Table contd. right side

\begin{tabular}{lllllll}
\hline \multicolumn{7}{c}{ MS } \\
\hline PH & CD & CN & SNC & SW & SY & HI \\
\hline $10674.09 * *$ & $560.18 * *$ & 68.05 & $10556.44 * *$ & $2789.47 * *$ & $703.28 * *$ & 0.0004 \\
$40.58 * *$ & $6.08 *$ & $15.41 * *$ & 4.07 & $25.46 * *$ & $5.76 *$ & 0.0005 \\
9.52 & 1.3 & $3.56 *$ & 6.94 & $7.92 * *$ & 1.21 & $0.0004 *$ \\
$559.82 * * *$ & $15.33 * * *$ & $63.87 * * *$ & $480.5 * * *$ & $107.67 * * *$ & $47.71 * * *$ & $0.011 * * *$ \\
$72.36 * * *$ & $5.07 * * *$ & $33.76 * * *$ & $143.94 * * *$ & $25.56 * * *$ & $38.96 * * *$ & $0.0074 * * *$ \\
7.71 & 1.35 & 2.15 & 7.98 & 4.53 & 1.09 & 0.0003 \\
17.15 & 10.28 & 24.37 & 25.25 & 17.59 & 36.35 & 33.14 \\
\hline
\end{tabular}

$*, * *$ and $* * *$ : significant at $0.05,0.01$ and 0.001 probability level, respectively.

DF: Days to $50 \%$ flowering, DM: Days to physiological maturity, PBN: Number of primary branches per plant, OBW: Outer bracts width, OBL: Outer bracts length, PH: Plant height, CD: Capitol diameter, CN: Number of capitols per plant, SNC: Number of seeds per capitol, SW: 1000-seed weight, SY: Seed yield per plant and HI: Harvest index per plant.

The genotype $\times$ environment interaction was significant for all characteristics. The highest PCV (29.04\%) was for harvest index and the lowest (5.33\%) was for days to physiological maturity. In the seed yield components, the number of seeds per capitol had the highest PCV (21.01\%). The estimated PCV for seed yield per plant was 19.201\%. The GCV varied from $4.65 \%$ (days to physiological maturity) to $17.34 \%$ (number of seeds per capitol). For other seed yield components, the GCV for number of capitols per plant was $12.69 \%$ and for 1000 -seed weight was $12.45 \%$. The GCV for seed yield per plant was very low (7.901\%, Table 4).

The highest broad-sense heritability was estimated for plant height using the variance components. Heritability was high for outer bract length, days to flowering, days to maturity and 
1000-seed weight. The lowest heritability was found for seed yield per plant. Of the yield components, 1000-seed weight and number of seeds per capitol had high heritability, but the heritability for number of capitols per plant was low (Table 4).

Table 3. Mean yield and agronomic traits of safflower genotypes by environment.

\begin{tabular}{lllllllllllll}
\hline & DF & DM & PBN & OBW & OBL & PH & CD & CN & SNC & SW & SY & HI \\
\hline Environ. 1 & 73.35 & 110.72 & 8.22 & 12.29 & 21.77 & 76.87 & 25.68 & 22.26 & 50.17 & 40.78 & 21.61 & 0.19 \\
Environ. 2 & 82.44 & 112.71 & 8.09 & 14.47 & 30.06 & 87.2 & 28.04 & 23.08 & 60.44 & 35.49 & 17.77 & 0.19 \\
LSD & 1.18 & 1.74 & 1.67 & 1.26 & 1.52 & 2.74 & 1.06 & 1.69 & 0.869 & 2.17 & 1.03 & 0.009 \\
$(\alpha=0.05)$ & & & & & & & & & & & & \\
\hline
\end{tabular}

DF: Days to $50 \%$ flowering, DM: Days to physiological maturity, PBN: Number of primary branches per plant, OBW: outer bracts width $(\mathrm{mm})$, OBL: Outer bracts length $(\mathrm{mm}), \mathrm{PH}$ : Plant height $(\mathrm{cm}), \mathrm{CD}$ : Capitol diameter $(\mathrm{mm}), \mathrm{CN}$ : Number of capitols per plant, SNC: Number of seeds per capitol, SW: 1000-seed weight (g), SY: Seed yield per plant (g) and HI: harvest index per plant.

Table 4. Mean, minimum and maximum variance components and heritability for 12 traits.

\begin{tabular}{lllllllllll}
\hline Trait & Mean & Min & Max & $\sigma_{\mathrm{e}}^{2}$ & $\sigma_{\mathrm{ge}}^{2}$ & $\sigma_{\mathrm{g}}^{2}$ & $\sigma_{\mathrm{ph}}^{2}$ & $\begin{array}{l}\mathrm{GCV} \\
(\%)\end{array}$ & $\begin{array}{l}\mathrm{PCV} \\
(\%)\end{array}$ & $\begin{array}{l}\mathrm{h}_{\mathrm{b}}^{2} \\
(\%)\end{array}$ \\
\hline FD & 77.8 & 68.50 & 100.75 & 2.374 & 15.417 & 22.109 & 31.241 & 6.04 & 7.184 & 70.769 \\
MD & 111.00 & 104.00 & 131.00 & 2.000 & 14.262 & 27.029 & 35.422 & 4.653 & 5.328 & 76.303 \\
PBN & 8.15 & 5.93 & 11.54 & 0.772 & 1.013 & 0.472 & 1.241 & 8.451 & 13.707 & 38.015 \\
OBW & 13.30 & 9.05 & 17.89 & 1.887 & 1.161 & 2.354 & 3.511 & 11.443 & 13.977 & 67.028 \\
OBL & 25.90 & 13.83 & 37.31 & 7.098 & 4.474 & 13.508 & 17.921 & 14.156 & 16.306 & 75.378 \\
PH & 82.00 & 60.65 & 118.85 & 7.715 & 35.558 & 134.05 & 155.73 & 14.11 & 15.208 & 86.079 \\
CD & 26.80 & 21.00 & 31.70 & 1.352 & 2.046 & 2.821 & 4.319 & 6.253 & 7.736 & 65.328 \\
CN & 22.60 & 13.15 & 34.46 & 2.153 & 17.386 & 8.281 & 18.435 & 12.691 & 18.937 & 44.918 \\
SNC & 55.30 & 30.18 & 90.50 & 7.987 & 74.779 & 92.553 & 135.880 & 17.34 & 21.01 & 68.115 \\
SW & 38.10 & 26.45 & 55.18 & 4.532 & 11.57 & 22.580 & 30.189 & 12.453 & 14.399 & 74.794 \\
SY & 19.60 & 7.68 & 42.86 & 1.089 & 20.834 & 2.405 & 14.163 & 7.901 & 19.2 & 16.978 \\
HI & 0.192 & 0.068 & 0.598 & 0.0003 & 0.0039 & 0.0009 & 0.003 & 15.41 & 29.042 & 28.155 \\
\hline
\end{tabular}

DF: Days to 50\% flowering, DM: Days to physiological maturity, PBN: Number of primary branches per plant, OBW: Outer bracts width (mm), OBL: Outer bracts length (mm), PH: Plant height $(\mathrm{cm}), \mathrm{CD}$ : Capitol diameter (mm), CN: Number of capitols per plant, SNC: Number of seeds per capitol, SW: 1000-seed weight (g), SY: Seed yield per plant (g) and HI: Harvest index per plant.

Safflower is compatible with areas with winter and spring rainfall and dry air during the flowering and maturity period. During and after flowering, high humidity or sequential rains can give rise to diseases that reduce safflower yield (Knowles 1989). The present research was carried out in two environments. Environment 2 had an earlier sowing date, which allowed more time to the beginning of warm weather and on the set of flowering, higher humidity in both air and soil than environment 1 . This increased the outer bract length and width, capitol diameter, number of seeds per capitol, days to flowering, day to maturity and plant height. Sprinkler irrigation and more humidity in the air during growth decreased the 1000-seed weight and seed yield in environment 2 . 
Omidi and Javidfar (2011) reported that an increase in relative air humidity during pollination decreased the percentage of pollinated flowers. Ashri et al. (1975) showed that safflower growth period from planting to flowering and plant height is strongly affected by environmental factors. In the present study, no significant difference was found between environments for the number of primary branches per plant, number of capitols per plant and the harvest index. A significant genotype $\times$ environment interaction for all characteristics indicates that the 100 safflower genotypes tested had dissimilar behavior in different environments.

The PCV and GCV specify the amount of genetic diversity for the assessed characteristics. In the present study, the PCV was higher than the GCV for all traits. The lowest PCV and GCV were recorded for days to physiological maturity. The number of seeds per capitol had the highest GCV and the highest PCV was for the harvest index. Omidi et al. (2009) reported that the GCV for days to maturity was very low (3.3) for spring safflower genotypes and the highest GCV (34.8) was estimated for seed yield. The highest and the lowest PCV were found for number of ineffective capitols (42\%) and days to maturity (3.3\%).

Asadi and Mozaffari (2006) reported high and low GCV and PCV values for number of seeds per capitol and days to 50\% flowering, respectively. Arslan (2007) recorded the highest PCV and GCV for seed yield. In the present study, the GCV for number of seeds per capitol agrees with those of Sirisha (2009). Arslan (2007) and Sirisha (2009) reported the highest GCV for seed yield $(34.79 \%)$ and number of capitols per plant $(32 \%)$. The highest PCV $(35.75 \%)$ was reported by Sirisha (2009) for seed yield per plant. The difference between the PCV and GCV for days to maturity, plant height, capitol diameter, days to flowering and 1000-seed weight was less than for the other traits and indicates the lowest environmental influence on these characteristics. These results are in accordance with the high estimate of heritability in these traits. The PCV for seed yield was $243.015 \%$ more than for GCV, signifying the lowest amount of heritability.

Heritability is a good indicator of the transmittal of traits from parent to progeny. The assessment of heritability helps in selection of the best genotypes from a varied genetic population. A high estimation of heritability increases the efficiency of selection for a special trait. Reddy et al. (2013) reported that heritability could be grouped as low (below 30\%), medium (30 $60 \%$ ) and high (above 60\%). In the present study, in accord with these classifications, studied characteristics can be classified into groups on the basis of their heritability. Group 1 had high heritability and comprised plant height, days to physiological maturity, days to flowering, 1000seed weight, number of seeds per capitol, capitol diameter, outer bract length and outer bract width. These traits are less influenced by the environment and are strongly controlled by genetic factors. The highest broad-sense heritability was estimated for plant height, which is in accordance with the results of Asadi and Mozaffari (2006), Camas and Esendal (2006) and Elfadl et al. (2010).

Heritability for number of seeds per capitol was also high and is in accordance with the results of Camas and Esendal (2006), Arslan (2007) and Sirisha (2009). High heritability estimation has been reported by Camas and Esendal (2006) and Arslan (2007) for 1000-seed weight. Asadi and Mozaffari (2006) reported high heritability in capitol diameter, which is in agreement with the present results. Camas and Esendal (2006) estimated low heritability for this trait. Heritability for days to maturity reported to be 0.69 by Asadi and Mozaffari (2006), 93\% by Sirisha (2009) and $78 \%$ by Elfadl et al. (2010) which are in conformity with the present result. Sirisha (2009) estimated heritability for days to flowering at 69.26 and $93 \%$, respectively, which are close to the present research results. In the present study, Group 2 comprised medium heritability and included the number of primary branches and number of capitols per plant. Camas and Esendal (2006) also assessed moderate heritability for the number of primary branches. Arslan (2007), however, assessed high heritability for this trait. The number of capitols per plant was estimated to be high 
by Arslan (2007) and Sirisha (2009) (78 and 83\%, respectively). Group 3 contained seed yield and harvest index and showed low heritability. The low estimation of heritability for seed yield was in accordance with the results of Camas and Esendal (2006), but it contrasted with the results of Arslan (2007), Sirisha (2009) and Elfadl et al. (2010).

BaĖnziger et al. (1997) reported that a decrease in environmental stress increases heritability. For high yield production, an increase in heritability derives more from an increase in genetic variance than from environment variance. Regardless of the magnitude of genetic and environmental variance, the amount of variance of the genotype $\times$ environment interaction could affect heritability (BaÈnziger et al.1997). Since the number of safflower genotypes and range of their grain yield were large, the reason for the low heritability and GCV could be the high genotype $\times$ environment interaction variance in the present study. In a study on safflower genotypes by Pourdad and Jamshid Moghaddam (2013), similar results were reported for yield components, including number of capitols per plant, number of seeds per capitol and 1000-seed weight. Seed yield and number of capitols per plant are strongly influenced by the environmental change; thus, these characteristics cannot be utilized as selection criteria in safflower breeding programs.

Heritable diversity is useful for stable genetic development (Singh 2006). In the study of quantitative traits, the most important duty of heritability is prediction of reliable phenotypic values as a guide to breeding value (Falconer and Mackay 1996).

Camas and Esendal (2006) suggested that the decreased influence of the environment on plant height, branching height and 1000-seed weight means they can be evaluated for selection in early generations. Arslan (2007) reported that environmental fluctuations have a greater influence on the number of primary branches and number of capitols per plant than on other traits.

In conclusion, it may be suggested that the high heritability of plant height, days to physiological maturity, days to flowering, 1000-seed weight, number of seeds per capitol and capitol diameter are less influenced by the environment and are more controlled by genetic factors. This makes these traits most appropriate for use in selection. Seed yield heritability was low; thus, direct selection will not be effective for its improvement. The number of seeds per capitol and 1000 -seed weight can be used for indirect increase in yield for different safflower varieties.

\section{References}

Al-Yassin A Grando S Kafawin O Tell A and Ceccarelli S 2005. Heritability estimates in contrasting environments as influenced by the adaptation level of barley germplasm. Ann. Appl. Biol. 147: 235244.

Arslan B 2007. Assessing of heritability and variance components of yield and some agronomic traits of different safflower (Carthamus tinctorius L.) cultivars. Asian Plant Sci. 6(3): 554- 557.

Asadi AA and Mozaffari K 2006. Relationship among yield components and selection criteria for yield improvement in safflower (Carthamus tinctorius L.). J. Appl. Sci. 6(13): 2853- 2855.

Ashri A, Zimmer DE, Urie AL and Knowles PF 1975. Evaluation of the germplasm collection of safflower (Carthamus tinctorius L.): VI. Length of planting to flowering period and plant height in Israel, Utah and Washington. Theor. Appl. Genet. 46: 359-364.

BaEnziger M, Betran FJ and Lafitte HR 1997. Effciency of high-nitrogen environments for improving maize for low-nitrogen target environments. Crop Sci. 37: 1103-1109.

Bleidere M 2002. Using of yield components for high yield selection. State stende plant breed station, Quant Genet Effic Breed. p. 7.

Camas N and Esendal E 2006. Estimates of broad sense heritability for seed yield and yield components of safflower (Carthamus tinctorius L.). Hereditas 143: 55-57. 
Elfadl E, Reinbrecht C and Claupein W 2010. Evaluation of phenotype variation in a world germplasm collection of safflower (Carthamus tinctorius L.) grown under organic farming conditions in Germany. Genet. Resour. Crop Evol. 57(2): 155-170.

Falconer DS and Mackay TFC 1996. Introduction to quantitative genetics. $4^{\text {th }}$ Edn , Longmans Green, Harlow, Essex, UK, pp. 480

Hill J, Becker HC and Tigerstedt PMA 1998. Quantitative and ecological aspects of plant breeding. Chapman Hall, London.

Knowles PF 1989. Safflower. In: Downey RK, Robbelen G, Ashri A (eds) Oil crops of the world: their breeding and utilization. McGraw-Hill Publishing Company, New York, pp. 363-374.

Li D and Mündel HH 1996. Safflower. IPK Corrensstrasse 306466 Gaterslebeny, Germany.

Mündel H and Bergman JW 2009. Safflower. In: Vollmann J, Rajcan I, editors. Handbook of plant breeding: oil crops. Springer, New York, pp. 423-447 and 548.

Omidi-Tabrizi AH 2005. Study of some important agronomic traits in spring safflower genotypes using principle components analysis. In: Proc $6^{\text {th }}$ The Internat Safflower Conf, 6- 10 June 2005, Istanbul, Turkey.

Omidi AH and Javidfar F 2011. Safflower. Agricultural education publication, Iran. (In Persian).

Omidi AH, Khazaei H and Hongbo Sh, 2009. Variation for some important agronomic traits in 100 spring safflower (Carthamus tinctorius L.) genotypes. American-Eurasian J. Agric. Environ. Sci. 5(6): 791-795.

Pourdad SS 2006. Safflower. Sepehr Pub, Iran. pp. 123 (Translated, In Persian).

Pourdad SS and Jamshid Moghaddam M 2013. Study on genetic variation in safflower collection (Carthamus tinctorius L.) under rainfed condition. Iranian Journal of Dry land Agriculture 1(3): 1-16 (In Persian).

Reddy MP, Reddy BN, Arsul BT and Maheshwari JJ 2013. Genetic variability, heritability and genetic advance of growth and yield components of linseed (Linum usitatissimum L.). Int. J. Curr. Microbiol. App. Sci. 2(9): 231-237.

Singh BD 2006. Plant Breeding: Principles and Methods. Kalyani Pub, New Delhi, India.

Singh RK and Chaudhary BD 1985. Biometrical methods in quantitative analysis. Kalyani Pub, New Delhi, India.

Sirisha M 2009. Studies on genetic divergence and character association in safflower (Carthamus tinctorius L.). M.Sc. thesis, Acharya N.G. Ranga Agric. Univ. India.

Toker C 2004. Estimates of broad-sense heritability for seed yield and yield criteria in faba (Vicia faba L.). Hereditas 140: 222-225.

Viana JMS and Regazzi AJ 1999. Estimation of genotypic parameters in the analysis square lattice experiment group. Bragantia, Campinas 58(1): 195-208.

Weiss EA 2000. Safflower. In: Oil seed crops. 2nd ed. Blackwell Sci, Oxford, London. 